\title{
Uma nova espécie do gênero Paratubana Young (Homoptera, Cicadellidae, Cicadellinae) ${ }^{1}$
}

\section{Rodney R. Cavichioli ${ }^{2}$}

\begin{abstract}
A new species of Paratubana YOUNG - P. webbi $s p$. $n$. (from Caruaru, PE, Brazil) is described.
\end{abstract}

Paratubana webbi sp. $\mathrm{n}$.

(Figs. 1 - 6)

Localidade-tipo: BRASIL. Pernambuco. Caruaru, iv. 1972. M. Alvarenga, B.M. 1972 - 541. (BM).

Medidas (em mm): Holótipo Macho: comprimento da cabeça: 0,52; distância transocular: 1,80; distância interocular: 1,12; distância ocelocular: 0,28 ; distância interocelar: 0,56 ; comprimento do pronoto: 1,00 ; distância entre os úmeros: 1,72 ; comprimento da tégmina: 6,60 ; largura máxima da tégmina: 1,44 ; comprimento total: 7,92 .

Holó tipo macho: cabeça, em vista dorsal, mais ou menos curta, de comprimento $2 / 7$ a $3 / 10$ da distância transocular e $4 / 9$ e $1 / 2$ da distância interocular, anteriormente arredondada, sem carena na transição entre a coroa e a face; ocelos situados sobre a linha imaginária que tangencia os bordos anteriores dos olhos, separados entre si por uma distância duas vezes a ocelocular; superfície da coroa glabra, com três fóveas, sendo duas entre os olhos e ocelos e uma mediana à frente dos ocelos; suturas laterais do clípeo estendendo-se sobre a coroa e atingindo os ocelos; lóbulos suprantenais não protuberantes, em vista lateral, carenados e oblíquos; olhos, em vista lateral, tão longos quanto largos; clípeo com largura basal 5/6 de seu comprimento, levemente achatado medianamente, com impressões musculares nítidas e de superfície finamente pontuada, de perfil levemente inclinado para trás; sutura transclipeal obsoleta medianamente; anteclípeo mais longo do que largo, de perfil com a porção apical levemente angulada; rostro atingindo as mesocoxas. Pronoto levemente mais estreito do que a cabeça, de comprimento $4 / 7$ a $3 / 5$ da distância entre os úmeros; disco liso; margens laterais retas, a posterior emarginada medianamente; carena notopleural inteira. Escutelo mais largo

1 Contribuiçåo n: 640, do Departamento de Zoologia - UFPR.

2 Entomólogo do Centro de Identificação de Insetos Fitófagos - UFPR, Caixa Postal 19030 - 81504 Curitiba - Pr. Bolsista do CNPq. 
basalmente do que longo; superfície lisa e sem estrias após o sulco mediano. Tégminas quatro vezes e meia mais longas do que largas, com três células anteapicais fechadas e quatro células apicais, sendo a base da quarta mais proximal do que a terceira; textura coriácea, exceto apicalmente; margem apical arredondada; asas posteriores quase tão longas quanto as tégminas e $R_{2}+3$ incompleta. Fórmula setal dos fêmures posteriores 2. 1. 1; basitarsos posteriores de comprimento maior do que a soma dos dois distais e com duas fileiras de cerdas na superfície plantar. Pigóforo mais longo do que largo, apicalmente arredondado; com macrocerdas distribuidas no terço apical; sem processos. Placa subgenital, triangular, bipartida, abruptamente afilada do meio para o ápice; ápice atingindo $2 / 3$ do comprimento do pigóforo; macrocerdas unisseridas e dispostas na margem lateral externa. Parâmeros não atingindo o ápice do conetivo, com lobo mediano e ápice afilados. Conetivo em Y invertido, com uma

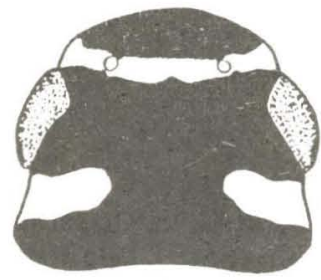

1
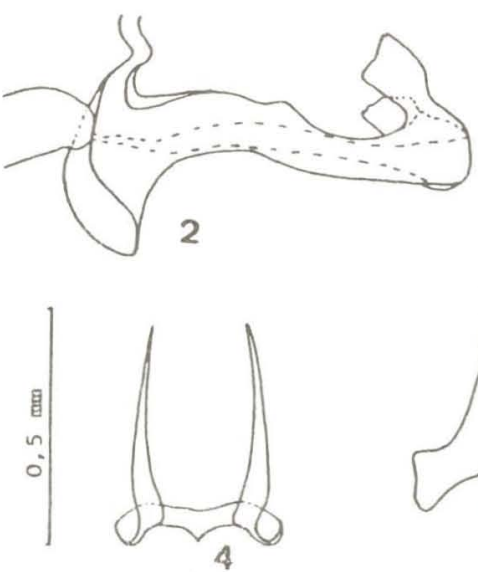
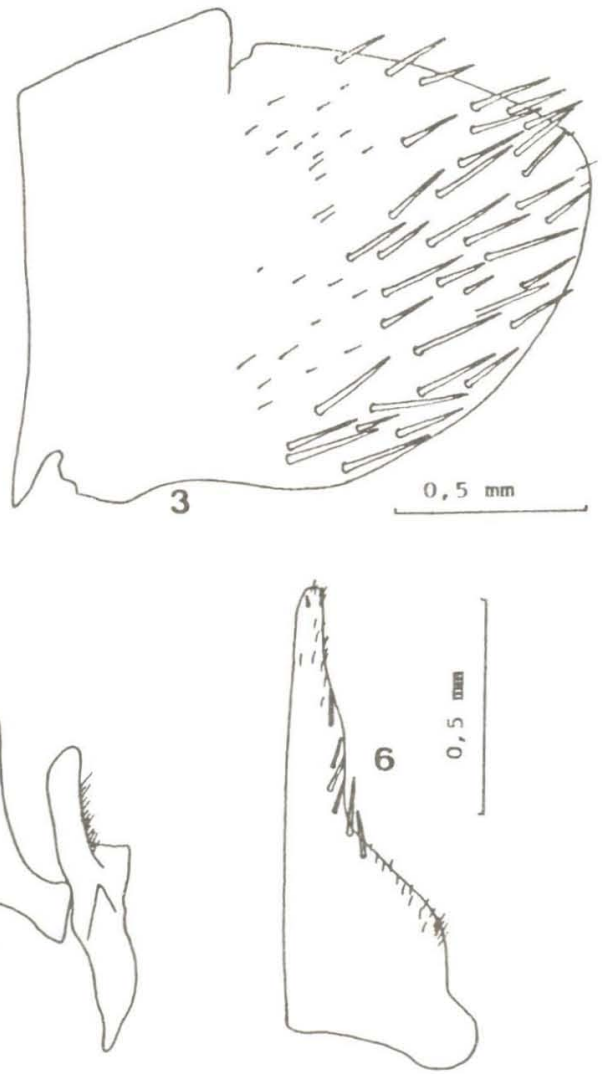

FIGS. 1 - 6: - Paratubana webbi sp. n. (Holotipo): 1 - cabeça e pronoto em vista dorsal; 2 - edeago em vista lateral; 3 - pigઠforo em vista lateral; 4 - paráfise em vista dorsal; 5 - conetivo e parâmero em vista dorsal; 6 - placa subgenital em vista ventral. 
leve carena mediana. Edeago alongado, subcilíndrico, levemente curvado para cima na sua base; com dois processos dorsoapicalmente, voltados para a base do edeago e com a margem apical serrilhada. Paráfise simétrica, mais curta que o edeago, com os ramos mais ou menos paralelos e afilados apicalmente.

Coloração: cabeça preta com uma faixa branca transversa, passando sobre os ocelos e estendendo-se lateralmente; clípeo com uma mancha branca de forma elíptica e alongada na porção mediana. Pronoto preto com duas manchas brancas, ovais, situadas látero-medianamente e estendendo atê o prepimero. Escutelo preto. Tégminas pretas, com seis manchas brancas: duas arredondadas no clavo, uma basal e outra próxima do ápice; quatro no cório, arredondadas, exceto áquela situada no terço apical: uma basal, próxima da sutura claval, situada um pouco à frente àquela da base do clavo; uma mediana, junto à margem costal; uma junto à sutura claval, na altura do ápice do clavo e a última, de forma alongada, situada no terço apical e estendida da margem costal ate a base da segunda célula apical.

Espécie dedicada ao Dr. Mick D. Webb do Bristish Museum (Natural History). 